\title{
Kendala Pengawasan Keuangan Negara
}

\author{
Revrisond Baswir
}

\section{Pendahuluan}

ikap kritis terhadap inefektivitas pengawasan akhir-akhir ini cenderung meningkat. Hal itu tidak hanya didorong oleh semakin transparannya praktek penyimpangan dalam pengelolaan keuangan negara, tapi juga oleh dampak negatifnya yang cenderung semakin memprihatinkan. Dilihat dari segi transparansi praktek penyimpangan, di satu pihak, jumlah penyimpangan yang berhasil dilacak oleh lembaga-lembaga pengawasan fungsional cenderung jauh berada di bawah perkiraan para pengamat. Di pihak yang lain, popularitas Indonesia sebagai salah satu negara juara korupsi justru cenderung meningkat.

Perhatikan beberapa data berikut. Ketika Prof. Sumitro Djojodihadikusumo menengarai bahwa tingkat kebocoran anggaran pembangunan setiap tahunnya telah mencapai angka 30\% (Republika, 12/01/1994), yang berhasil dilacak oleh BPKP ternyata tidak lebih dari sekitar 3 persen. Sementara itu, temuan penelitian yang dilaporkan oleh beberapa lembaga riset internasional seperti Transparancy Internasional dari Jerman dan Political and Economic Risk Consultancy (PERC) dari Hongkong, hampir selalu menempatkan Indonesia pada posisi puncak urutan negara-negara juara korupsi di dunia.
Sedangkan dilihat dari segi dampak negatifnya, inefektivitas pengawasan setidak-tidaknya telah menyebabkan semakin sulitnya upaya penanggulangan tiga persoalan berikut: Pertama, persoalan kesenjangan ekonomi. Secara historis, kesenjangan ekonomi dapat ditelusuri sejak jaman kolonial. Namun demikian, inefektivitas pengawasan telah menyebabkan terjadinya mis-alokasi sumber daya nasional bagi keuntungan sekelompok orang yang memiliki akses ke dalam lingkungan birokrasi (Baswir, 1995a). Akibatnya, sumber daya nasional yang dapat dibagikan untuk menolong mereka yang tertinggal dalam proses pembangunan cenderung sangat terbatas.

Bandingkan misalnya antara jumlah kerugian negara dalam kasus Bapindo-Edy Tansil dengan jumlah dana yang tersedia untuk pelaksanaan program IDT selama tiga tahun. Jumlah kerugian negara dalam kasus pembobolan Bapindo hampir mencapai $R p$ 1,3 trilyun. Sedangkan untuk pelaksanaan program IDT, dana yang tersedia bagi berjuta-juta penduduk miskin di 60.000 desa tertinggal hanya berjumlah sekitar $R p$ 1,2 trilyun.

Kedua, persoalan dominasi konglomerasi. Persoalan dominasi konglomerasi cenderung tidak banyak mendapat perhatian dalam peta persoalan ekonomi nasional. Bahkan, sementara pihak cenderung meng- 
anggap perusahaan-perusahaan konglomerasi tersebut sebagai aset nasional yang tak ternilai harganya. Padahal, selain berkaitan dengan persoalan misalokasi sumberdaya dan kesenjangan ekonomi, dominasi konglomerasi telah menyebabkan lembahnya daya saing dunia usaha indonesia dalam arena kompetisi global. Akibatnya, jangankan menjadi kekuatan untuk menembus pasar internasional, perusahaanperusahaan konglomerasi itu justru menjadi pemicu meruncingnya kecemburuan dan kerusuhan sosial (Baswir, 1995b).

Ketiga, persoalan inefisiensi ekonomi nasional. Sebagaimana terungkap dalam angka Incremental Capital Output Ratio (ICOR), inefisiensi perekonomian Indonesia termasuk yang paling rendah di Asean. Ketika angka ICOR negara-negara asean, kecuali Filipina, telah mencapai tingkat 3,5 persen, angka ICOR Indonesia masih berkutat pada tingkat 4,9 persen. Dengan tingkat inefisiensi yang sangat memprihatinkan itu, perekonomian Indonesia tidak hanya dilanda oleh penyakit ekonomi biaya tinggi, tapi sekaligus menghadapi kendala dalam mendorong masuknya investasi asing ke negeri ini.

Pertanyaannya adalah, kendala apakah sebenarnya yang dihadapi oleh akuntan pemerintah dalam menjalankan fungsi kepengawasannya? Tulisan ini bermaksud menjawab pertanyaan tersebut. Untuk itu, berikut akan dikemukakan terlebih dulu gambaran singkat mengenai mekanisme pengawasan. Setelah itu barulah dikemukakan mengenai peranan dan kendala akuntan pemerintah dalam melaksanakan pengawasan.

\section{Mekanisme Pengawasan}

Pengawasan keuangan negara merupakan bagian integral dari pengelolaan keuangan negara. Berdasarkan pengertiannya, pengawasan keuangan negara menca- kup segala tindakan untuk menjamin agar pengelolaan keuangan negara berjalan sesuai dengan rencana, aturan, dan ketentuan perundang-undangan yang berlaku (Baswir, 1995c). Sedangkan berdasarkan objeknya, pengawasan keuangan negara meliputi baik pengawasan aparatur negara, pengawasan APBN, pengawasan BUMN, maupun pengawasan barang-barang milik negara.

Bila ditelusuri lebih jauh, mekanisme pengawasan keuangan negara dapat dibedakan menjadi pengawasan internal dan pengawasan eksternal. Pengawasan internal adalah mekanisme pengawasan keuangan negara yang dilakukan oleh pemerintah secara internal dalam lingkungan birokrasi. pemerintah. Dalam garis besarnya, penyelenggaraan pengawasan internal ini dapat dipilih menjadi pengawasan internal melalui sistem pengawasan dan pengawasan internal melalui lembaga-lembaga pengawasan.

Pengawasan internal melalui sistem pengawasan adalah unsur pengawasan internal yang diselenggarakan oleh pemerintah dengan mengembangkan sistem pengawasan sebagai bagian integral dari tatakerja kelembagaannya. Karena tanggung jawab atas berjalan atau tidaknya sistem pengawasan internal ini-melekat di pundak setiap atasan, maka ia kemudian cenderung lebih dikenal sebagai pengawasan atasan langsung atau pengawasan melekat. Melalui mekanisme pengawasan atasan langsung atau pengawasan melekat ini, pemerintah bermaksud mengendalikan setiap kegiatan aparaturnya sehingga dapat dijaga kesesuaiannya dengan rencana, ketentuan, dan undang-undang yang berlaku (Sujamto, 1989).

Pengawasan internal melalui lembagalembaga pengawasan atau dikenal sebagai pengawasan fungsional, dapat dibedakan menjadi pengawasan internal dalam arti sempit dan pengawasan internal dalam arti 
luas. Pengawasan internal dalam arti sempit adalah pengawasan internal yang dilakukan oleh pemerintah dengan membentuk instansi pengawas pada setiap unit organisasi dalam lingkungan birokrasi pemerintahan.

Dalam pengawasan internal dalam arti sempit ini, aparat pengawas dan pihak yang diawasi sama-sama bernaung di bawah pimpinan departemen, lembaga non-departemen, atau daerah yang sama. Dalam struktur organisasi pemerintahan, lembaga yang bertugas melaksanakan fungsi pengawasan internal dalam arti sempit ini adalah: Inspektorat Jenderal Departemen (lijendep), Inspektorat Wilayah Propinsi (Itwilprop), Inspektorat Wilayah Daerah Kabupaten (Itwilkab), dan Inspektorat Wilayah Daerah Kotamadya (Itwilkod).

Pengawasan internal dalam arti luas adalah pengawasan internal yang dilakukan oleh pemerintah dengan membentuk lembaga khusus pengawasan yang wewenangnya mencakup seluruh bagian organisasi dalam lingkungan birokrasi pemerintah. Walaupun aparat pengawasan dan pihak yang diawasi dalam pengawasan internal dalam arti luas ini sama-sama bernaung dalam lingkup birokrasi, namun masing-masing berasal dari lingkungan departemen atau lembaga non-departemen yang berbeda.

Tujuan pengawasan internal dalam arti luas ini tidak hanya untuk melakukan verifikasi, tapi juga untuk membantu pihak yang diawasi dalam menunaikan tugasnya. Dalam struktur organisasi pemerintahan, fungsi pengawasan internal dalam arti luas ini diselenggarakan oleh Badan Pengawas Keuangan dan Pembangunan (BPKP) dan Inspektur Jenderal Pembangunan (Irjenbang).

Pelaksanaan kedua unsur pengawasan internal sebagaimana di atas dikoordinasikan oleh Menko Eku-Wasbang, yaitu pada setiap departemen, kantor Menko, kantor Menteri Negara, lembaga pemerintah non departemen, serta di setiap daerah, berdasarkan petunjuk Wakil Presiden. Pelaksanaan koordinasi ini dilakukan dengan menyusun rencana tahunan dan evaluasi hasil-hasilnya sebagai bahan untuk penyusunan rencana pengawasan tahun berikutnya (Bohari, 1992).

Sesuai dengan pasal 1 lampiran Instruksí Presiden Nomor 15/1983, sasarannya adalah sebagai berikut: Pertama, terlaksananya tugas umum pemerintahan secara tertib didasarkan pada perundangundangan yang berlaku serta didasarkan pada sendi-sendi kewajaran penyelenggaraan pemerintahan. Kedua, terlaksananya pembangunan sesuai dengan rencana serta peraturan perundang-undangan yang berlaku sehingga tercapai sasaran yang ditetapkan. Dan ketiga, tercegahnya pemborosan, kebocoran dan penyimpangan dalam penggunaan wewenang, tenaga, uang dan perlengkapan milik negara, sehingga dapat terbina aparatur yang tertib, bersih, berwibawa, berhasil guna (efektif), dan berdaya guna (efisien).

Sedangkan pengawasan eksternal adalah pengawasan keuangan negara yang dilakukan oleh suatu lembaga pengawasan yang sama sekali berada di luar birokrasi pemerintahan. Dalam mekanisme pengawasan eksternal ini, hubungan antara pengawas dengan pihak yang diawasi tidak lagi mengandung sifat kedinasan. Di Indonesia, fungsi pengawasan eksternal ini antara lain diselenggarakan oleh DPR, Badan Pemeriksa Keuangan (BPK), dan secara langsung oleh masyarakat.

Pengawasan eksternal oleh DPR dikenal juga sebagai pengawasan legislatif, yaitu suatu bentuk pengawasan yang dilakukan oleh lembaga perwakilan rakyat terhadap kebijakan serta pelaksanaan tugastugas umum pemerintahan dan pembangunan.

Sehubungan dengan APBN, pemerintah tidak hanya harus meminta pengesahan 
RAPBN terhadap DPR, tapi juga harus mempertanggungjawabkan pelaksanaannya kepada lembaga ini.

Sama seperti DPR, BPK adalah sebuah lembaga tinggi negara yang berada di luar birokrasi pemerintahan. Namun demikian, berbeda dari DPR yang memiliki wewenang lebih luas, titik berat perhatian $\mathrm{BPK}$ dalam penyelenggaraan pengawasan dibatasi pada aspek pengelolaan keuangan negara. Tugas pokoknya adalah melakukan pemeriksaan terhadap Perhitungan Anggaran Negara (PAN) yang disusun oleh Direktorat Jenderal Anggaran.

BPK kemudian harus memberikan pendapatnya terhadap PAN tersebut. Karena pendapat BPK ini merupakan bagian dari Rancangan Undang-Undang Perhitungan Anggaran Negara (RUU-PAN) yang akan diserahkan oleh pemerintah kepada DPR, berarti pendapat BPK itu merupakan masukan bagi DPR dalam mempertimbangkan pertanggungjawaban pemerintah dalam pengelolaan keuangan negara (Koenarto, 1996).

Bentuk pengawasan yang juga termasuk dalam kategori pengawasan eksternal adalah pengawasan yang secara langsung dilakukan oleh masyarakat, atau dikenal sebagai pengawasan masyarakat. Dilihat dari sudut pengertiannya, pengawasan masyarakat adalah suatu bentuk pengawasan yang dilakukan oleh warga masyarakat terhadap pemerintah atau aparatur-aparaturnya, baik disampaikan secara lisan maupun secara tertulis. Pengawasan masyarakat ini dapat dilakukan secara perorangan atau secara kelembagaan. Salah satu media penyalurannya adalah melalui Tromol Pos 5000.

\section{Kendala Akuntan Pemerintah}

Berdasarkan mekanisme pengawasan sebagaimana di atas, peranan akuntan pemerintah dalam pengawasan keuangan ne- gara dapat dipetakan dengan jelas. Akuntan pemerintah, yang dalam hal ini meliputi baik akuntan-akuntan pemeriksa yang bekerja dalam lingkungan birokrasi pemerintah, maupun akuntan-akuntan pemeriksa yang bekerja di lembaga tinggi negara khusus pemeriksaan, dalam garis besarnya dapat berperan sebagai akuntan pemeriksa melalui berbagai bentuk dan tingkatan lembaga pengawasan fungsional. Secara internal, akuntan pemerintah dapat berperan sebagai pemeriksa melalui BPKP, Irjendep, Itwilprop, Itwilkod, dan Itwilkab. Sedangkan secara eksternal, akuntan pemerintah dapat berperan sebagai pemeriksa melalui BPK.

Dengan peranan yang sangat luas tersebut, akuntan pemerintah sesungguhnya menempati kedudukan yang sangat strategis dalam proses pengelolaan keuangan negara di Indonesia. Pertanyaannya adalah, faktor apakah yang menghambat akuntan pemerintah dalam menjalankan fungsi kepengawasannya?

Bahwa penyimpangan dalam praktek pengelolaan keuangan negara cenderung semakin transparan, dan dampak negatifnya terhadap berbagai persoalan ekonomi nasional cenderung semakin memprihatinkan, maka pertanyaan mengenai kendala pelaksanaan fungsi pengawasan akuntan pemerintah itu memang perlu mendapat perhatian. Sebab, dengan menjawab pertanyaan tersebut tidak hanya efektivitas fungsi pengawasan akuntan pemerintah diharapkan dapat ditingkatkan, tapi meluasnya praktek penyimpangan dalam pengelolaan keuangan negara juga diharapkan dapat dikurangi.

Secara garis besar, lima faktor yang cenderung menghambat pelaksanaan fungsi akuntan pemerintah dalam melakukan pengawasan keuangan negara adalah sebagai berikut: Pertama, jumlah akuntan pemerintah secara keseluruhan jauh dari memadai. Menurut data yang tersedia, jumlah 
pegawai BPKP pada tahun 1996 hanya tercatat sekitar 8000 orang, sedangkan pegawai BPK hanya sekitar 2000 orang. Dari jumlah itu, hanya sebagian kecil yang memiliki latar belakang pendidikan akuntansi. Dengan jumlah yang sangat minim itu, maka kemampuan akuntan pemerintah dalam mengawasi seluruh komponen keuangan negara cenderung sangat terbatas.

Kedua, kedudukan akuntan pemerintah dalam struktur organisasi lembaga-lembaga pengawasan internal cenderung sangat lemah. Sebagaimana diketahui, bidang pengawasan keuangan hanyalah merupakan sebagian dari seluruh bidang pengawasan yang dijalankan oleh lembaga-lembaga pengawasan internal tersebut. Secara keseluruhan, lingkup pengawasan yang dijalankan oleh lembaga-lembaga pengawasan internal seperti BPKP, Irjendep, Itwilprop, Itwilkod, dan Itwilkab itu dapat dibagi menjadi sepuluh bidang sebagai berikut: bidang pemerintahan, bidang sosial-politik, bidang aparatur/kepegawaian, bidang perekonomian, bidang kesejahteraan sosial, bidang pendapatan dan perijinan, bidang badan usana milik negara, bidang kekayaan negara, bidang pengelolaan anggaran belanja rutin, dan bidang pengelolaan anggaran belanja pembangunan (Itjen Depdagri, 1993).

Dengan kedudukan seperti itu, maka di satu pihak wajar bila tidak seluruh pegawai BKPK, Itjendep, Itwilprop, dan Itwilkod/ Itwilkab, berlatar belakang profesi akuntansi. Bahkan, dengan tercakupnya bidang pemerintah dan sosial-politik sebagai bagian integral fungsi kepengawasan lembaga-lembaga itu, duduknya mantan camat, mantan bupati, atau perwira ABRI sebagai pimpinan lembaga-lembaga tersebut sulit dihindari. Di pihak yang lain, karena hampir semua persoalan yang berkaitan pemerintahan memiliki dimensi politik, maka dominannya peranan pertimbangan politik dalam menindaklanjuti temuan penyimpangan keuangan negara sulit dielakkan (Baswir dkk., 1977).

Ketiga, kedudukan BPK terhadap pemerintah cenderung kurang seimbang. Walaupun secara formal BPK memiliki kedudukan yang sama tinggi dengan pemerintah, namun dalam implementasinya hal itu sulit dilaksanakan, baik karena ditempatkannya mantan pejabat atau anggota $A B R I$ sebagai anggota BPK maupun karena terbatasnya jumlah anggaran yang dialokasikan kepada lembaga ini. Ketua dan Wakil Ketua BPK periode 1993 - 1998 misalnya, dijabat oleh mantan Menteri Keuangan Prof. JB. Sumarlin dan Mantan Kapolri Letjen. Pol. Koenarto. Sedangkan jumlah anggaran yang dialokasikan untuk BPK, rata-rata hanya sekitar 0,043 persen dari volume APBN setiap tahunnya (Kepala Perwakilan BPKDIY, 1997). Akibatnya, BPK cenderung tampak lebih akrab dengan pemerintah daripada dengan DPR. Sebaliknya, karena kewajiban BPK terhadap DPR hanya bersifat pemberitahuan, maka DPR sering tidak memiliki informasi terinci mengenai hasil pemeriksaan BPK (Bohari, 1992).

Keempat, koordinasi antar sesama lembaga pengawasan cenderung masih lemah (Bako, 1996). Hal itu tidak hanya tampak dalam lemahnya koordinasi antara lembaga-lembaga pengawasan internal dengan lembaga pengawasan eksternal, tapi juga di antara sesama lembaga pengawasan internal itu sendiri. Di satu pihak, temuan lembaga pengawasan internal seringkali tidak didukung oleh lembaga pengawasan eksternal, demikian pula sebaliknya. Di pihak yang lain, praktek pengawasan yang dijalankan oleh sesama lembaga pengawasan internal cenderung tumpang tindih. Hal tersebut tidak hanya berdampak pada rendahnya efektivitas pengawasan, tapi juga menyebabkan tumbuhnya citra negatif terhadap lembaga pengawasan secara menyeluruh. 
Kelima, praktik kenegaraan yang dilaksanakan di Indonesia secara keseluruhan dapat dikategorikan sebagai negara korporatis (Chalmmers, 1996). Dalam praktik kenegaraan seperti itu, pembagian kekuasaan antara eksekutif, -legislatif, dan yudikatif, sulit dikembangkan. Bahkan, dalam bidang politik, kehadiran partai oposisi cenderung diharamkan. Akibatnya, tersusunnya struktur kenegaraan yang meletakkan birokrasi pemerintahan di puncak piramida kekuasaan sulit dihindari. Lebih-lebih dalam struktur pemerintahan daerah yang menempatkan Kepala Daerah sebagai penguasa tunggal pelaksanaan pembangunan daerah. Dengan struktur seperti itu, efektifitas fungsi pengawasan keuangan negara memang sulit ditingkatkan. Dalam kenyataannya, praktik penyimpangan dalam pengelolaan keuangan negara justru cenderung semakin melembaga.

Memperhatikan kelima kendala pengawasan keuangan negara sebagaimana di atas, maka efektifitas mekanisme pengawasan dalam struktur pemerintah kita memang patut dipertanyakan. Bila lembagalembaga tinggi negara dan daerah yang keberadannya dilindungi oleh konstitusi pun tidak mampu menjalankan fungsi pengawasannya dengan baik, maka rendahnya efektivitas lembaga-lembaga pengawasan secara menyeluruh menjadi mudah dipahami. Hal itu tidak hanya disebabkan oleh terbatasnya jumlah akuntan pemerintah, atau karena lemahnya koordinasi antar sesama lembaga pengawasan, yang utama adalah karena sangat kuatnya hegemoni pemerintah terhadap lembaga-lembaga tinggi negara yang lain. Akibatnya, tidak hanya lembaga-lembaga pengawasan internal yang cenderung tidak berdaya, DPR dan BPKM pun cenderung hanya berfungsi sebagai subordinat pemerintah.

\section{Kesimpulan}

Dengan latar belakang seperti itu, ma$\mathrm{ka}$ tindakan apakah yang harus dilakukan untuk meningkatkan peranan akuntan pemerintah dalam pengawasan keuangan negara di Indonesia? Secara kelembagaan, berbagai faktor yang menghambat efektivitas fungsi pengawasan sebagaimana dipaparkan di atas perlu segera ditanggulangi. Sehubungan dengan jumlah akuntan pemerintah misalnya, baik yang terdapat di BPKP, Itjendep, Itwilprop, dan Itwilkod/ Itwilkab, maupun yang terdapat di BPK, periu segera ditambah. Untuk itu, masingmasing lembaga pengawasan tersebut periu mendapat alokasi anggaran yang lebih besar.

Sehubungan dengan lemahnya kedudukan akuntan pemerintah dalam hampir semua lembaga pengawasan yang ada, maka perlu segera diupayakan penempatan akuntan pemerintah pada posisi yang lebih strategis pada masing-masing lembaga tersebut. Jabatan Itjendep, Itwilprop, dan Itwilkod/ltwilkab misalnya, sepatutnya dialihkan secara bertahap kepada para akuntan. Dengan demikian, penempatan mantan pejabat atau anggota $A B R I$ pada masingmasing lembaga itu perlu dipertimbangkan untuk dikurangi. Khusus untuk keanggotaan BPK, ditempatkannya akuntan-akuntan yang berasal dari perguruan tinggi atau dari sektor swasta sebagai anggota lembaga ini, selayaknya dicoba. Bahkan, jika mungkin, jabatan Ketua atau Wakil Ketua BPK secara khusus diperuntukkan bagi akuntan-akuntan profesional, baik yang berasal dari dalam maupun dari luar birokrasi pemerintahan.

Akhirnya, karena praktik penyimpangan dalam pengelolaan keuangan negara sangat erat kaitannya dengan kelemahan struktural yang terdapat dalam tatanan kenegaraan kita, maka penanggulangannya dalam jangka panjang tidak dapat dipisahkan dari dilakukannya reformasi struktural 
yang berlingkup kenegaraan pula. Artinya, karena persoalan mendasar yang kita hadapi dalam meningkatkan efektivitas fungsi pengawasan secara menyeluruh adalah persoalan sangat dominannya peranan pemerintah, khususnya bila dibandingkan dengan lembaga-lembaga tinggi negara yang lain, maka dilakukannya reformasi struktural untuk meningkatkan peranan DPR, BPK, dan Mahkamah Agung dalam mengawasi pemerintah, perlu mendapat perhatian.

\section{Daftar Pustaka}

Bako, RSH (1996), Mengkaji Efektivitas Pengawasan Keuangan Negara, dalam Harian Suara Pembaharuan, 25 April.

Baswir, Revrisond (1995a), Dialektika Kesenjangan, Konglomerasi, dan Korupsi dalam Pembangunan Ekonomi Indonesia, dalam A. Abimanyu dkk. (1997), Pembangunan Ekonomi dan Pemberdayaan Rakyat, BPFE, Yogyakarta.

, (1995b), Bahaya Dominasi Konglomerasi, dalam Harian Media Indonesia, 13 Nopember. (1995c), Akuntansi Pemerintahan Indonesia, Edisi 3, BPFE, Yogyakarta.

Baswir, Revrisond, Fahmi Radhi dan Setyono (1997), Tanggapan Informasi Masyarakat dalam Tromol Pos 5000 Yang Tergolong "Tidak Mengandung Kebenaran," (Japoran penelitian), kerjasama Sekretariat Negara RI dengan PPE-FE UGM, Yogyakarta.
Bohari, (1992), Pengawasan Keuangan Negara, Rajawali Pers, Jakarta.

Chalmers, lan (1996), Konglomerasi: Negara dan Modal dalam Industri Otomotif, Gramedia, Jakarta.

Sujamto, J. (1989), Aspek-aspek Pengawasan di Indonesia, Sinar Grafika, Jakarta.

Djojohadikusumo, Sumitro (1994), Mengungkap 30 Persen Kebocoran Anggaran, dalam Harian Republika, 12 14 Januari.

Kepala Perwakilan II BPK DIY (1997), Peranan Akuntan Pemerintah (Auditor) dalam Pengawasan Keuangan $\mathrm{Ne}$ gara (makalah tidak dipublikasikan), disajikan dalam Panel Forum Nasional Peningkatan Efektifitas Pengawasan Keuangan Negara, Himpunan Mahasiswa Akuntansi FE-UMY, di Yogyakarta, 20 Maret.

Koenarto (1996), Dengan BEPEKA yang Profesional, Efektif, Efisien, dan Modern, Menuju Hari Esok Yang Lebih Baik, PEMERIKSA, Edisi Khusus No. $60-61$, Januari.

Republik Indonesia (1983), Instruksi Presiden No. 15/1983 tentang Pengawasan Keuangan Negara, Sekretariat Negara, Jakarta.

Itjen Depdagri (1993), Pedoman Pemeriksaan Reguler Aparat Pengawasan Fungsional di Jajaran Departemen Dalam Negeri (Edisi Penyempurnaan), Depdagri, Jakarta. 